PROFESI (Profesional Islam)

Media Publikasi Penelitian; 2018; Volume 15; No 2.

Website: ejournal.stikespku.ac.id

\title{
Pengaruh Jus Buah Kurma terhadap Kadar Hemoglobin dan Jumlah Sel Darah pada Pasien Kanker Paru dengan Kemoterapi
}

\author{
Setiyawan* 1), Erlina Windyastuti $^{2)}$ \\ 1) Prodi Sarjana Keperawatan, STIKes Kusuma Husada Surakarta \\ ${ }^{2)}$ Prodi D3 Keperawatan, STIKes Kusuma Husada Surakarta \\ *email: stikes_kh@yahoo.com
}

Kata Kunci

Hemoglobin, Jus Kurma,

Kemoterapi, Sel Darah

\begin{abstract}
Abstrak
Kemoterapi merupakan salah satu penatalaksanaan pasien kanker yaitu pemberian senyawa kimia (obat kanker) untuk mengurangi, menghilangkan atau menghambat pertumbuhan parasit atau mikroba ditubuh pasien. Namun, obat kemoterapi dapat menekan atau merusak sel-sel sumsum tulang sehingga produksi sel-sel darah berkurang dan menimbulkan efek, anemia, leukopenia, dan trombositopenia. Reaktivitas radikal bebas akibat kemoterapi dapat dihambat oleh sistem antioksidan yang terdapat pada sayuran dan buahbuahan. Berbagai literatur menyatakan bahwa konsumsi buah kurma dapat mengurangi pertumbuhan sel kanker sebagai antioksidan dan mengatasi anemia, karena buah kurma mengandung zat-zat yang dibutuhkan tubuh untuk pembentukan dan maturasi sel-sel darah. Penelitian ini bertujuan untuk mengetahui pengaruh jus buah kurma terhadap kadar hemoglobin dan jumlah sel darah (eritrosit, leukosit, dan trombosit) pada pasien kanker paru dengan kemoterapi. Penelitian kuantitatif pre test post test control group design pada 15 responden kelompok intervensi dan 15 responden kelompok kontrol dengan teknik simple random sampling sesuai kriteria inklusi dan eksklusi. Hasil: Hasil uji statistik paired t-test menunjukkan terdapat pengaruh jus buah kurma terhadap kadar hemoglobin $(p=0.000)$ dan sel darah yaitu eritrosit $(p=0.000)$, leukosit $(p=0.006)$ dan trombosit (0.018). Simpulan penelitian menunjukkan tenaga keperawatan/kesehatan diharapkan mampu menyusun perencanaan tindakan keperawatan mandiri atau kolaborasi yaitu pemberian jus buah kurma bagi pasien kanker yang menjalani kemoterapi sebagai bagian dari penerapan ilmu komplementer.
\end{abstract}

\section{The Effect of Dates Palm Juice on Hemoglobin Level and Blood Cell Count of Leeng Concer Patients with Chemateraphy}

Keywords

Hemoglobin, Date Palm Juice, Chemotherapy, Blood Cells

\begin{abstract}
Chemotherapy is one of the management of cancer patients is the provision of chemical compounds (cancer drugs) to reduce, eliminate or inhibit the growth of parasites or microbes in the patient's body. However, chemotherapy drugs can suppress or damage bone marrow cells so that the production of blood cells is reduced and cause effects, anemia, leukopenia, and thrombocytopenia. Free radical reactivity due to chemotherapy can be inhibited by the antioxidant system found in vegetables and fruits. Various literature states that the consumption of dates can reduce the growth of cancer cells as antioxidants and overcome anemia, because the dates contain substances that the body needs for the formation and maturation of blood cells. The aim of this study is to determine the effect of date palm juice on hemoglobin levels and blood cell
\end{abstract}


PROFESI (Profesional Islam)

Media Publikasi Penelitian; 2018; Volume 15; No 2.

Website: ejournal.stikespku.ac.id

count (erythrocytes, leukocytes, and platelets) in lung cancer patients with chemotherapy. Quantitative research of pre test post test control group design on 15 respondents of intervention group and 15 control group respondents with simple random sampling technique according to inclusion and exclusion criteria. The result of paired t-test statistic showed that there was influence of date palm juice to hemoglobin $(p=0.000)$ and erythrocytes $(p=0.000)$, leukocytes $(p=0.006)$ and platelets (0.018). Conclusion: Nursing or health workers are expected to develop independent nursing care planning or collaboration that is giving date palm juice to cancer patients undergoing chemotherapy as part of the application of complementary science.

\section{PENDAHULUAN}

Organisasi Kesehatan Dunia (WHO) memperkirakan jumlah penderita kanker paru didunia 8.8 juta jiwa. $^{13}$ Data Kemenkes tahun 2015, menunjukkan bahwa penderita kanker paru di Indonesia adalah 1,59 juta jiwa. Karsinoma paru di Indonesia menduduki peringkat ke-4 dari seluruh kanker yang sering ditemukan di rumah sakit. ${ }^{1}$ Data rekam medis tahun 2016 di RSUD dr. Moewardi menunjukkan penderita kanker paru sebesar 484 kasus. ${ }^{1}$ Kematian disebabkan karena pertumbuhan sel-sel kanker yang tidak terkendali secara normal dan sering disertai dengan kaheksia dan neutropenia. Keadaan ini merupakan akibat dari kanker baik lokal maupun sistemik dan juga merupakan efek samping dari obat anti kanker. Kemoterapi yang merupakan salah satu penatalaksaan pengobatan kanker juga berkontribusi terhadap keadaan tersebut. Selain mual, muntah, anoreksia, kemoterapi juga mempunyai efek penekanan terhadap sumsum tulang yang dapat menyebabkan terjadinya anemia, leukopenia, dan trombositopenia. ${ }^{6}$

Telah banyak tindakan yang dilakukan untuk mengatasi efek radikal dari obat kemoterapi tersebut, baik tindakan medis maupun tindakan keperawatan. Kolaborasi pemberian obat dan transfusi darah untuk meningkatkan kadar hemoglobin dan sel-sel darah pasien merupakan salah satu tindakan yang telah dilakukan selama ini. Namun, tindakan tersebut tentunya memberikan konsekuensi bagi pasien dan keluarga karena membutuhkan dana yang cukup besar. Berdasarkan literatur yang telah dipelajari menyebutkan bahwa efek radikal bebas akibat kemoterapi dapat dihambat oleh sistem antioksidan yang dapat diperoleh melalui sayuran dan buah-buahan yang mengandung antioksidan tinggi. ${ }^{3}$
Penggunaan makanan dan nutraceutical merupakan salah satu terapi komplementer dan sesuai dengan teori keperawatan Florence Nigtingale. Dalam konsep nutraceutical diyakini bahwa makanan atau bagian dari makanan memberikan manfaat bagi kesehatan dan dapat digunakan sebagai obat, termasuk sebagai pencegahan terhadap penyakit. ${ }^{7}$ Salah satu sumber makanan yang termasuk nutraceutical adalah buah kurma. Penelitian-penelitian yang sudah ada menyebutkan bahwa ekstrak kurma dapat meningkatkan kadar $\mathrm{Hb}$ darah secara in vitro pada tikus putih jantan, namun peningkatan ini tidak bermakna secara statistik, sejauh ini peneliti belum menemukan adanya penelitian yang menyebutkan bahwa buah kurma dapat mengatasi leukopenia dan trombositopenia, tetapi berdasarkan teori dapat dijelaskan bahwa asam folat yang terkandung dalam buah kurma dapat meningkatkan leukosit dan trombosit dalam batas normal. ${ }^{9}$ Melihat fenomena tersebut maka perlu dilakukan penelitian ini.

Berdasarkan latar belakang tersebut diatas, penulis tertarik untuk meneliti, pengaruh jus buah kurma terhadap kadar hemoglobin dan jumlah sel darah pada pasien kanker paru dengan kemoterapi.

\section{TUJUAN}

Tujuan dari penelitian ini adalah mengetahui untuk mengetahui pengaruh jus buah kurma terhadap kadar hemoglobin dan jumlah sel darah (eritrosit, leukosit, dan trombosit) pada pasien kanker dengan kemoterapi.

\section{METODE}

Penelitian ini merupakan penelitian kuantitatif dengan design pre dan post test group with control. Penelitian ini dilakukan di RSUD dr. 
PROFESI (Profesional Islam)

Media Publikasi Penelitian; 2018; Volume 15; No 2.

Website: ejournal.stikespku.ac.id

Moewardi Surakarta. Sampel pada penelitian ini adalah 15 responden pada kelompok intervensi dan 15 responden pada kelompok kontrol dengan menggunakan teknik simple random sampling.

Instrumen yang digunakan dalam pengumpulan data menggunakan ceklist data demografi dan hasil pengukuran sel-sel darah responden dan format evaluasi pemberian jus buah kurma. Pemberian jus kurma dilakukan pada kelompok intervensi yaitu jus buah kurma sebanyak 200 gram/hari dengan dua kali pemberian (pagi dan sore hari sebelum makan) pada $250 \mathrm{cc}$ setiap kali minum, selama 7 hari pemberian.

Teknik analisis data menggunakan uji paired t-test dengan tingkat kepercayaan 95\% untuk mengetahui pengaruh jus buah kurma terhadap kadar hemoglobin dan jumlah sel darah (eritrosit, leukosit, dan trombosit) pada pasien kanker dengan kemoterapi.

\section{HASIL PENELITIAN Analisis Univariat}

Hasil analisis univariat karakteristik responden dari distribusi umur pasien kanker yang menjalani kemoterapi hampir merata untuk masing-masing kelompok umur yaitu pada kelompok intervensi dewasa tua $53,3 \%$ (8 responden) dan dewasa tengah 46,7\%, (7 responden) sedangkan pada kelompok kontrol didapatkan bahwa dewasa tua $60 \%$ (9 responden) dan dewasa madya adalah $40 \%$ (6 responden).

Usia responden berada pada rentang usia 4160 tahun dan usia lebih dari 60 tahun baik pada kelompok kontrol atau intervensi dan hampir memiliki kesetaraan. Usia dewasa dibagi berdasarkan psikologi perkembangan yang dapat berfungsi dalam mengidentifikasi fase-fase perkembangan yaitu dewasa muda (usia 18-40 tahun), dewasa madya (usia 41-60 tahun) dan masa lanjut usia (usia $>60$ tahun). ${ }^{8}$ Peningkatan usia dihubungkan dengan proses penuaan dan berdasarkan hasil penelitian ini kanker banyak ditemukan pada umur di atas 41 - 60 tahun atau lebih.

Distribusi jenis kelamin pasien kanker didominasi oleh laki-laki baik kelompok intervensi maupun kelompok kontrol yaitu masingmasing $86.7 \%$ dan $80 \%$. Karakteristik responden berdasarkan jenis kelamin lebih $80 \%$ adalah jenis kelamin laki-laki. Dalam penelitian ini, memberikan keterangan bahwa jenis kelamin laki-laki cederung memiliki potensial terjadinya kanker paru yang dimungkinkan oleh pengaruh gaya hidup yaitu perokok. Jenis kelamin laki-laki lebih rentan dengan penyakit kritis dan degeneratif yang memerlukan dukungan. Hal ini berkaitan dengan penyakit kardio-vaskuler dan pernafasan pada laki-laki lebih tinggi daripada perempuan dimana kemampuan fisiologi jantung dan paru cenderung mengalami penurunan pada usia 35-45 yang berhubungan dengan pola hidup dan kebiasaan merokok. ${ }^{10}$

Hasil analisis pada siklus kemoterapi didapatkan data bahwa siklus kemoterapi pasien kanker yang menjalani kemoterapi sebagian besar pada kelompok intervensi dan kontrol dengan siklus dua kali sebesar $46.7 \%$ dan $66.7 \%$.

Distribusi responden berdasarkan siklus kemoterapi pasien kanker pada kelompok kontrol dan intervensi memiliki kesetaraan. Obat kemoterapi tidak diberikan secara sekaligus, biasanya 4-8 siklus untuk mencegah kerusakan permanen dari sel sehat. Jumlah sel darah tidak dengan segera menurun setelah kemoterapi dimulai karena obat-obat sitotoksik tidak membunuh sel-sel dalam aliran darah. Obat kemoterapi mencegah sumsum tulang dari pembentukkan sel-sel darah baru. Rata-rata umur sel darah putih adalah enam jam, sel darah merah 120 hari, dan platelet 10 hari. $^{4}$

Hasil analisis data sebelum pemberian jus kurma, berdasarkan derajad keganasan pada kelompok intervensi dan kontrol sebagian besar derajat keganasan pasien kanker yang menjalani kemoterapi adalah derajat sedang sebesar $93.3 \%$ dan $86.7 \%$. Derajat keganasan tinggi tidak ditemukan pada kedua kelompok.

Secara teori, derajad keganasan dilihat dari klasifikasi hispatologi. ${ }^{1} \quad$ Derajad keganasan mempengaruhi pemberian kemoterapi dan siklusnya karena pengukuran keberhasilan tindakan suatu terapi bidang onkologi adalah dengan menilai angka respon tumor (respone tumor rate) dan kemampuan hidup bebas penyakit (disease free survival). ${ }^{6}$ Pada stadium derajad keganasan ringan tidak menimbukan gejala sama sekali dan semakin besar derajad-nya semakin jelas gejalanya, dan biasanya ditandai dengan batuk, nafas pendek, (meta-stasis paru), sakit pada abdomen, ikterus pada tulang (metastasis tulang). Pendektesian meta-stasis biasanya dilakukan pemeriksaan darah, $x$-ray, 
PROFESI (Profesional Islam)

Media Publikasi Penelitian; 2018; Volume 15; No 2.

Website: ejournal.stikespku.ac.id

MRI, dan biopsy. Perubahan sel darah secara tidak langsung dapat digunakan untuk membantu menentukan derajad keganansan. ${ }^{14}$

Hasil analisis data berdasarkan status nutrisi didapatkan bahwa pada kelompok intervensi dan kontrol sebagian besar status nutrisi pasien kanker yang menjalani kemoterapi adalah baik (53.3\%) dibandingkan status nutrisi kurang. Distribusi responden berdasarkan status nutrisi pasien kanker yang menjalani kemoterapi pada kelompok kontrol dan intervensi memiliki kesetaraan yaitu $53.3 \%$ status nutrisi baik dan $46.7 \%$ sedang. Jumlah sel darah merah (eritrosit) dan hemoglobin dapat dipakai untuk menentukan status nutrisi pasien, sedangkan leukosit dan trombosit lebih mengarah pada status imunologi. Status nutrisi dapat memprakirakan toleransi serta respon pasien terhadap terapi. Salah satu penyebab kebutuhan nutrisi meningkat karena adanya cedera pada sel dan jaringan yang berhubungan dengan terapi seperti pembedahan, radioterapi atau kemoterapi. ${ }^{6}$ Kemoterapi mengakibatkan berbagai efek antara lain adalah anemia, leukopenia dan trombositopenia. Hal ini disebabkan karena obat sitotoksik menyerang selsel kanker yang sifatnya cepat membelah, namun terkadang obat ini juga memiliki efek pada sel-sel tubuh normal yang mempunyai sifat cepat membelah seperti sumsum tulang. Sumsum tulang merupakan bagian yang esensial dari hemopoesis. Maturasi sel-sel darah tergantung pada jumlah zat- zat makanan yang adekuat dan penggunaannya yang sesuai, seperti vitamin B12, asam folat, protein, zat besi, dan tembaga. ${ }^{6,10}$

Hasil analisis data sebelum intervensi didapatkan bahwa rata-rata $\mathrm{Hb}$ jus buah kurma pada pasien kanker yang menjalani kemoterapi pada kelompok intervensi $11.18 \mathrm{gr} / \mathrm{dl}(95 \% \mathrm{CI}$ : 10.46 - 11.90) dengan standar deviasi $1.31 \mathrm{gr} / \mathrm{dl}$. Sedangkan hasil analisis data pada kelompok kontrol didapatkan bahwa rata-rata $\mathrm{Hb}$ sebelum intervensi pasien kanker yang menjalani kemoterapi $10.73 \mathrm{gr} / \mathrm{dl}(95 \% \mathrm{CI}: 9.89$ - 11.57) dengan standar deviasi $1.52 \mathrm{gr} / \mathrm{dl}$ (Tabel 1).

Pada Tabel. 2. Jumlah sel darah dari rata-rata eritrosit sebelum intervensi jus buah kurma pada pasien kanker yang menjalani kemoterapi pada kelompok intervensi 4.59 juta/ul (95\% CI: $4.36-$ 4.81) dengan standar deviasi 0.41 juta/ul. Sedangkan hasil analisis data pada kelompok kontrol didapatkan bahwa rata-rata eritrosit sebelum intervensi pasien kanker yang menjalani kemoterapi 4.31 juta/ul (95\% CI: 4.074.56) dengan standar deviasi 0.44 juta/ul.

Tabel 1. Distribusi Responden Berdasarkan Kadar Hemoglobin

Sebelum Intervensi Jus Buah Kurma

\begin{tabular}{lccccc}
\hline Variabel & Mean & Median & SD & Min-Mak & $95 \%$ CI \\
\hline Hemoglobin & & & & & \\
- Intervensi & 11.18 & 11.50 & 1.31 & $9.00-13.2$ & $10.46-11.90$ \\
- Kontrol & 10.73 & 10.40 & 1.52 & $8.9-13.8$ & $9.89-11.57$ \\
\hline
\end{tabular}

Tabel 2. Distribusi Responden Berdasarkan Sel Darah

Sebelum Intervensi Jus Buah Kurma

\begin{tabular}{lccccc}
\hline Variabel & Mean & Median & SD & Min-Mak & $95 \%$ CI \\
\hline $\begin{array}{l}\text { Sel Darah: } \\
\text { Eritrosit }\end{array}$ & & & & & \\
$\quad-\quad$ Intervensi & 4.59 & 4.60 & 0.41 & $3.80-5.20$ & $4.36-4.81$ \\
$\quad$ Kontrol & 4.31 & 4.30 & 0.44 & $3.60-5.00$ & $4.07-4.56$ \\
$\begin{array}{l}\text { Leukosit } \\
\quad \quad \text { Intervensi }\end{array}$ & 6.93 & 6.50 & 1.83 & $3.90-10.1$ & $5.93-7.95$ \\
- Kontrol & 6.75 & 5.90 & 2.08 & $4.20-10.2$ & $5.60-7.90$ \\
Trombosit & & & & & \\
$-\quad$ Intervensi & 285.47 & 283.0 & 88.31 & $155-414$ & $237-334$ \\
$-\quad$ Kontrol & 244.40 & 239.0 & 72.26 & $143-402$ & $204-284$ \\
\hline
\end{tabular}


PROFESI (Profesional Islam)

Media Publikasi Penelitian; 2018; Volume 15; No 2.

Website: ejournal.stikespku.ac.id

Rata-rata leukosit sebelum intervensi jus buah kurma pada pasien kanker yang menjalani kemoterapi kelompok intervensi $6.93 \mathrm{ribu} / \mathrm{ul}$ (95\% CI: 5.93 - 7.95) dengan standar deviasi $1.83 \mathrm{ribu} / \mathrm{ul}$. Sedangkan hasil analisis data pada kelompok kontrol didapatkan bahwa rata-rata leukosit sebelum intervensi pasien kanker yang menjalani kemoterapi 6.75 ribu/ul $(95 \% \mathrm{CI}$ : 5.60-7.90) dengan standar deviasi $2.08 \mathrm{ribu} / \mathrm{ul}$.

Rata-rata trombosit sebelum intervensi jus buah kurma pada pasien kanker yang menjalani kemoterapi kelompok intervensi $285.47 \mathrm{ribu} / \mathrm{ul}$ (95\% CI: 237 - 334) dengan standar deviasi $88.31 \mathrm{ribu} / \mathrm{ul}$. Sedangkan hasil analisis data pada kelompok kontrol didapatkan rata-rata trombosit sebelum intervensi pasien kanker yang menjalani kemoterapi 244.40 ribu/ul (95\% CI: 204 - 284) dengan standar deviasi $72.26 \mathrm{ribu} / \mathrm{ul}$.

Hasil analisis data sesudah didapatkan bahwa rata-rata $\mathrm{Hb}$ intervensi jus buah kurma pada pasien kanker yang menjalani kemoterapi pada kelompok intervensi $12.13 \mathrm{gr} / \mathrm{dl}(95 \% \mathrm{CI}$ : 11.49 - 12.14) dengan standar deviasi $1.14 \mathrm{gr} / \mathrm{dl}$. Sedangkan hasil analisis data pada kelompok kontrol didapatkan bahwa rata-rata $\mathrm{Hb}$ sebelum intervensi pasien kanker yang menjalani kemoterapi 10.23 gr/dl (95\% CI: 9.41 - 11.04) dengan standar deviasi $1.47 \mathrm{gr} / \mathrm{dl}$.

Pada Tabel. 4. Rata-rata eritrosit sesudah intervensi jus buah kurma pada pasien kanker yang menjalani kemoterapi pada kelompok intervensi 4.89 juta/ul (95\% CI: $4.64-5.15)$ dengan standar deviasi 0.46 juta/ul. Sedangkan hasil analisis data pada kelompok kontrol didapatkan bahwa rata-rata eritrosit sebelum intervensi pasien kanker yang menjalani kemoterapi 4.08 juta/ul (95\% CI: 3.82 - 4.34) dengan standar deviasi $0,47 \mathrm{juta} / \mathrm{ul}$.

Rata-rata leukosit sesudah intervensi jus buah kurma pada pasien kanker yang men-jalani kemoterapi pada kelompok intervensi 7.14 ribu/ul (95\% CI: 6.14 - 8.14) dengan standar deviasi $1.80 \mathrm{ribu} / \mathrm{ul}$. Sedangkan hasil analisis data pada kelompok kontrol didapatkan bahwa rata-rata leukosit sebelum intervensi pasien kanker yang menjalani kemoterapi $6.57 \mathrm{ribu} / \mathrm{ul}$ (95\% CI: 5.50 - 7.65) dengan standar deviasi $1.94 \mathrm{ribu} / \mathrm{ul}$.

Rata-rata trombosit sesudah intervensi jus buah kurma pada pasien kanker yang menjalani kemoterapi pada kelompok intervensi 315.20 ribu/ul (95\% CI: 266 - 364) dengan standar deviasi 88.48 ribu/ul. Sedangkan hasil analisis data pada kelompok kontrol didapatkan bahwa rata-rata trombosit sebelum intervensi pasien kanker yang menjalani kemoterapi 241.53 ribu/ul (95\% CI: 202 - 281) dengan standar deviasi $71.23 \mathrm{ribu} / \mathrm{ul}$.

Tabel 3. Distribusi Responden Berdasarkan Kadar Hemoglobin

Sesudah Intervensi Jus Buah Kurma Pada Kelompok Intervensi dan Kontrol

\begin{tabular}{lccccc}
\hline Variabel & Mean & Median & SD & Min-Mak & $95 \%$ CI \\
\hline Hemoglobin & & & & & \\
$-\quad$ Intervensi & 12.13 & 12.60 & 1.14 & $10.1-13.9$ & $11.49-12.14$ \\
$-\quad$ Kontrol & 10.23 & 9.60 & 1.47 & $8.5-13.2$ & $9.41-11.04$ \\
\hline
\end{tabular}

Tabel 4. Distribusi Responden Berdasarkan Sel Darah Sesudah Intervensi Jus Buah Kurma Pada Kelompok Intervensi dan Kontrol

\begin{tabular}{lccccc}
\hline Sel Darah & Mean & Median & SD & Min-Mak & $95 \%$ CI \\
\hline Eritrosit & & & & & \\
$\quad-\quad$ Intervensi & 4.89 & 4.90 & 0.46 & $4.00-6.00$ & $4.64-5.15$ \\
- Kontrol & 4.08 & 4.00 & 0.47 & $3.30-4.90$ & $3.82-4.34$ \\
Leukosit & & & & & \\
$\quad-\quad$ Intervensi & 7.14 & 6.8 & 1.80 & $3.70-10.0$ & $6.14-8.14$ \\
- Kontrol & 6.57 & 5.8 & 1.94 & $3.90-10.1$ & $5.50-7.65$ \\
Trombosit & & & & & \\
- Intervensi & 315.20 & 356.0 & 88.48 & $168-420$ & $266-364$ \\
- Kontrol & 241.53 & 234.0 & 71.23 & $138-400$ & $202-281$ \\
\hline
\end{tabular}


PROFESI (Profesional Islam)

Media Publikasi Penelitian; 2018; Volume 15; No 2.

Website: ejournal.stikespku.ac.id

\section{Analisis Bivariat}

\section{Hasil uji pre dan post intervensi}

Hasil uji homogenitas dengan Fisher F dari setiap variabel dependent dalam penelitian ini didapatkan nilai $p$ value $>0,05$ maka data tersebut homogen, hasil perbedaan rata-rata kadar hemoglobin dan nilai sel darah sebelum dan sesudah intervensi yang diuji dengan paired t-test adalah:

\section{Hemoglobin}

Rata-rata kadar hemoglobin pada kelom-pok intervensi sebelum diberikan intervensi jus buah kurma adalah $11.18 \mathrm{gr} / \mathrm{dl}$ dengan standar deviasi $1.31 \mathrm{gr} / \mathrm{dl}$. Pada pengukuran setelah diberikan jus buah kurma didapatkan rata-rata kadar hemoglobin adalah $12.13 \mathrm{gr} / \mathrm{dl}$ dengan standar deviasi $1.14 \mathrm{gr} / \mathrm{dl}$. Hasil uji statistik beda dua mean untuk sampel berpasangan menunjukkan adanya perbedaan rata-rata kadar hemoglobin yang signifikan dengan nilai $p=0.000$. Hal ini diperkuat hasil selisih rata-rata kadar hemoglobin sebelum dan sesudah pemberian jus buah kurma menunjukkan peningkatan $0.95 \mathrm{gr} / \mathrm{dl}$.

Rata-rata kadar hemoglobin pada kelompok kontrol sebelum diberikan intervensi jus buah kurma adalah $10.73 \mathrm{gr} / \mathrm{dl}$ dengan standar deviasi $1.52 \mathrm{gr} / \mathrm{dl}$. Pada pengukuran setelah diberikan jus buah kurma didapatkan rata-rata kadar hemoglobin adalah 10,23 gr/dl dengan standar deviasi $1.47 \mathrm{gr} / \mathrm{dl}$. Hasil uji statistik beda dua mean untuk sampel berpasangan menunjukkan adanya perbedaan rata-rata kadar hemoglobin yang signifikan dengan nilai $p=0.000$. Hal ini diperkuat dengan hasil selisih rata-rata kadar hemoglobin sebelum dan sesudah pemberian jus buah kurma menunjukkan penurunan $0.5 \mathrm{gr} / \mathrm{dl}$.

Tabel 5. Distribusi Responden Berdasarkan Perbedaan Rata-Rata Kadar Hemoglobin Sebelum dan Sesudah Intervensi Pada Kelompok Intervensi dan Kelompok Kontrol

\begin{tabular}{llllll}
\hline Variabel & Kelompok & $\mathrm{N}$ & Mean & SD & pValue \\
\hline Hemoglobin & Intervensi & & & & \\
- Sebelum & & 15 & 11.18 & 1.31 & 0.000 \\
- Sesudah & & 15 & 12.13 & 1.14 & \\
& Kontrol & & & & \\
- Sebelum & & 15 & 10.73 & 1.52 & 0.000 \\
- Sesudah & & 15 & 10.23 & 1.47 & \\
\hline
\end{tabular}

\section{Eritrosit}

Rata-rata nilai eritrosit pada kelompok intervensi sebelum diberikan intervensi jus buah kurma adalah 4.59 juta/ul dengan standar deviasi 0.41 juta/ul. Pada pengukuran setelah diberikan jus buah kurma didapatkan rata-rata nilai eritrosit adalah $4.89 \mathrm{juta} / \mathrm{ul}$ dengan standar deviasi 0.46 juta/ul. Hasil uji statistik beda dua mean untuk sampel berpasangan menunjukkan adanya perbedaan rata-rata nilai eritrosit yang signifikan dengan nilai $\mathrm{p}=0.002$. Hal ini diperkuat dengan hasil selisih rata-rata nilai eritrosit sebelum dan sesudah pemberian jus buah kurma yang menunjukkan peningkatan $0.3 \mathrm{juta} / \mathrm{ul}$.
Rata-rata nilai eritrosit pada kelompok kontrol sebelum diberikan intervensi jus buah kurma adalah 4.31 juta/ul dengan standar deviasi 0.44 juta/ul. Pada pengukuran setelah diberikan jus buah kurma didapatkan rata-rata nilai eritrosit adalah 4.08 juta/ul dengan standar deviasi 0.47 juta/ul. Hasil uji statistik beda dua mean untuk sampel berpasangan menunjukkan adanya perbedaan rata-rata nilai eritrosit yang signifikan dengan nilai $\mathrm{p}=0.000$. Hal ini diperkuat dengan hasil selisih rata-rata nilai eritrosit sebelum dan sesudah pemberian jus buah kurma yang menunjukkan penurunan 0.23 juta/ul. 
PROFESI (Profesional Islam)

Media Publikasi Penelitian; 2018; Volume 15; No 2.

Website: ejournal.stikespku.ac.id

Tabel 6. Distribusi Responden Berdasarkan Perbedaan Rata-Rata Eritrosit Sebelum dan Sesudah Intervensi Pada Kelompok Intervensi dan Kelompok Kontrol

\begin{tabular}{llllll}
\hline Variabel & Kelompok & $\mathrm{N}$ & Mean & SD & pValue \\
\hline Eritrosit & Intervensi & & & & \\
- Sebelum & & 15 & 4.59 & 0.41 & 0.002 \\
- Sesudah & & 15 & 4.89 & 0.46 & \\
& Kontrol & & & & \\
- Sebelum & & 15 & 4.31 & 0.44 & 0.000 \\
- Sesudah & & 15 & 4.08 & 0.47 & \\
\hline
\end{tabular}

\section{Leukosit}

Rata-rata nilai leukosit pada kelompok intervensi sebelum diberikan jus buah kurma adalah $6.93 \mathrm{ribu} / \mathrm{ul}$ dengan standar deviasi 1.83 ribu/ul. Pada pengukuran sesudah diberikan jus buah kurma didapatkan rata-rata nilai leukosit adalah $7.14 \mathrm{ribu} / \mathrm{ul}$ dengan standar deviasi 1,80 ribu/ul. Hasil uji statistik beda dua mean untuk sampel berpasangan menunjukkan adanya perbedaan rata-rata nilai leukosit yang signifikan dengan nilai $p=0.000$. Hal ini diperkuat dengan hasil selisih rata-rata nilai leukosit sebelum dan sesudah pemberian jus buah kurma yang menunjukkan peningkatan $0.21 \mathrm{ribu} / \mathrm{ul}$.
Rata-rata nilai leukosit pada kelompok kontrol sebelum diberikan jus buah kurma adalah $6.75 \mathrm{ribu} / \mathrm{ul}$ dengan standar deviasi $2.08 \mathrm{ribu} / \mathrm{ul}$. Pada pengukuran sesudah diberikan jus buah kurma didapatkan rata-rata nilai leukosit adalah $6.57 \mathrm{ribu} / \mathrm{ul}$ dengan standar deviasi $1.94 \mathrm{ribu} / \mathrm{ul}$. Hasil uji statistik beda dua mean untuk sampel berpasangan menunjukkan adanya perbedaan rata-rata nilai leukosit yang signifikan dengan nilai $\mathrm{p}=0.000$. Hal ini diperkuat dengan hasil selisih rata-rata nilai leukosit sebelum dan sesudah pemberian jus buah kurma yang menunjukkan penurunan $0.18 \mathrm{ribu} / \mathrm{ul}$.

Tabel 7. Distribusi Responden Berdasarkan Perbedaan Rata-Rata Leukosit Sebelum dan Sesudah Intervensi Pada Kelompok Intervensi dan Kelompok Kontrol

\begin{tabular}{llllll}
\hline Variabel & Kelompok & $\mathrm{N}$ & Mean & SD & pValue \\
\hline Leukosit & Intervensi & & & & \\
- Sebelum & & 15 & 6.93 & 1.83 & 0.000 \\
- Sesudah & & 15 & 7.14 & 1.80 & \\
& Kontrol & & & & \\
- Sebelum & & 15 & 6.75 & 2.08 & 0.000 \\
- Sesudah & & 15 & 6.57 & 1.94 & \\
\hline
\end{tabular}

\section{Trombosit}

Rata-rata nilai trombosit pada kelompok intervensi sebelum diberikan intervensi jus buah kurma adalah $285.47 \mathrm{ribu} / \mathrm{ul}$ dengan standar deviasi 88.3 ribu/ul. Pada pengukuran setelah diberikan jus buah kurma didapatkan rata-rata nilai trombosit adalah $315.20 \mathrm{ribu} / \mathrm{ul}$ dengan standar deviasi 88.5 ribu/ul. Hasil uji statistik beda dua mean untuk sampel berpasangan (paired sample correlations) menunjukkan adanya perbedaan rata-rata nilai trombosit yang signifikan dengan nilai $\mathrm{p}=0.000$. Hal ini diperkuat dengan hasil selisih rata-rata nilai trombosit sebelum dan sesudah pemberian jus buah kurma yang menunjukkan peningkatan $29.73 \mathrm{ribu} / \mathrm{ul}$.

Rata-rata nilai trombosit pada kelompok kontrol sebelum diberikan intervensi jus buah kurma adalah $244.40 \mathrm{ribu} / \mathrm{ul}$ dengan standar deviasi $72.3 \mathrm{ribu} / \mathrm{ul}$. Pada pengukuran setelah diberikan jus buah kurma didapatkan rata-rata nilai trombosit adalah $241.53 \mathrm{ribu} / \mathrm{ul}$ dengan standar deviasi 71.2 ribu/ul. Hasil uji statistik beda dua mean untuk sampel berpasangan (paired 
PROFESI (Profesional Islam)

Media Publikasi Penelitian; 2018; Volume 15; No 2.

Website: ejournal.stikespku.ac.id

sample correlations) menunjukkan adanya perbedaan rata-rata nilai trombosit yang signifikan dengan nilai $\mathrm{p}=0.000$. Hal ini diperkuat dengan hasil selisih rata-rata nilai trombosit sebelum dan sesudah pemberian jus buah kurma yang menunjukkan penurunan 2.87 ribu/ul.

Tabel 8. Distribusi Responden Berdasarkan Perbedaan Rata-Rata Trombosit Sebelum dan Sesudah Intervensi Pada Kelompok Intervensi dan Kelompok Kontrol

\begin{tabular}{llllll}
\hline Variabel & Kelompok & $\mathrm{N}$ & Mean & SD & pValue \\
\hline Trombosit & Intervensi & & & & \\
- Sebelum & & 15 & 285.47 & 88.3 & 0.000 \\
- Sesudah & & 15 & 315.20 & 88.5 & \\
& Kontrol & & & & \\
- Sebelum & & 15 & 244.40 & 72.3 & 0.000 \\
- Sesudah & & 15 & 241.53 & 71.2 & \\
\hline
\end{tabular}

\section{Hasil uji beda dua kelompok}

Hasil uji beda kelompok intervensi dan kelompok kontrol didapatkan data yaitu rata-rata kadar hemoglobin $(\mathrm{Hb})$ pada kelompok intervensi adalah $12.13 \mathrm{gr} / \mathrm{dl}$ dengan standar deviasi 1.14 gr/dl, sedangkan pada kelompok kontrol rata-rata kadar Hbnya adalah $10.23 \mathrm{gr} / \mathrm{dl}$ dengan standar deviasi $1.47 \mathrm{gr} / \mathrm{dl}$. Hasil uji statistik menunjukkan bahwa ada perbedaan yang signifikan rata-rata kadar $\mathrm{Hb}$ sesudah intervensi jus buah kurma antara kelompok kontrol dan intervensi $(\mathrm{p}=$ $0.000)$.

Rata-rata nilai eritrosit pada kelompok intervensi adalah 4.89 juta/ul dengan standar deviasi 0.46 juta/ul, sedangkan pada kelompok kontrol rata-rata nilai eritrositnya adalah 4.08 juta/ul dengan standar deviasi 0.47 juta/ul. Hasil uji statistik menunjukkan bahwa ada perbedaan yang signifikan rata-rata nilai eritrosit sesudah intervensi jus buah kurma antara kedua kelompok $(\mathrm{p}=0.000)$.

Rata-rata nilai leukosit pada kelompok intervensi adalah $7.14 \mathrm{ribu} / \mathrm{ul}$ dengan standar deviasi $1.80 \mathrm{ribu} / \mathrm{ul}$, sedangkan pada kelompok kontrol rata-rata nilai leukositnya adalah 6.57 ribu/ul dengan standar deviasi 1.92 ribu/ul. Hasil uji statistik menunjukkan bahwa ada per-bedaan yang signifikan rata-rata nilai leukosit sesudah intervensi jus buah kurma antara keduaa kelompok $(\mathrm{p}=0.006)$.

Tabel 9. Analisis Responden Berdasarkan Perbedaan Rata-rata Kadar Hemoglobin dan Nilai Sel Darah Sesudah Intervensi Pada Kelompok Intervensi dan Kelompok Kontrol

\begin{tabular}{lcccl}
\hline Variabel & $\mathrm{N}$ & Mean & $\mathrm{SD}$ & pValue \\
\hline Hemoglobin & & & & \\
$-\quad$ Intervensi & 15 & 12.13 & 1.14 & 0.000 \\
- Kontrol & 15 & 10.23 & 1.47 & \\
Eritrosit & & & & \\
$-\quad$ Intervensi & 15 & 4.89 & 0.46 & 0.000 \\
- Kontrol & 15 & 4.08 & 0.47 & \\
Leukosit & & & & \\
$-\quad$ Intervensi & 15 & 7.14 & 1.80 & 0.006 \\
$-\quad$ Kontrol & 15 & 6.57 & 1.92 & \\
Trombosit & & & & \\
$-\quad$ Intervensi & 15 & 315.20 & 88.48 & 0.018 \\
$-\quad$ Kontrol & 15 & 241.53 & 71.23 & \\
\hline
\end{tabular}


PROFESI (Profesional Islam)

Media Publikasi Penelitian; 2018; Volume 15; No 2.

Website: ejournal.stikespku.ac.id

Rata-rata nilai trombosit pada kelompok intervensi adalah $315.20 \mathrm{ribu} / \mathrm{ul}$ dengan standar deviasi 88.48 ribu/ul, sedangkan pada kelompok kontrol rata-rata nilai trombositnya adalah 241.53 ribu/ul dengan standar deviasi 71.23 ribu/ul. Hasil uji statistik menunjukkan bahwa ada perbedaan yang signifikan rata-rata nilai trombosit sesudah intervensi jus buah kurma antara kelompok kontrol dan intervensi $(p=0,018)$.

\section{PEMBahaSAN}

Hasil penelitian didapatkan bahwa pada pasien kanker yang menjalani kemoterapi yang mendapat jus buah kurma selama tujuh hari dengan pemberian dua kali sehari mengalami kenaikan hemoglobin dengan rata-rata peningkatannya adalah $0.95 \mathrm{gr} / \mathrm{dl}$. Sedangkan pada pasien kanker yang menjalani kemoterapi tetapi tidak mendapatkan jus buah kurma menunjukkan penurunan kadar hemoglobin dengan rata-rata penurunannya adalah $0.5 \mathrm{gr} / \mathrm{dl}$. Peningkatan tersebut bermakna secara statistik namun secara klinis dijelaskan bahwa nilai hemoglobin bermakna secara klinis apabila terdapat peningkatan minimal $1 \mathrm{gr} / \mathrm{dl} .{ }^{17}$ Pada kemoterapi akan terjadi destruksi pada sumsum tulang, dimana obat kemoterapi mendestruksi sumsum tulang sehingga terjadi penurunan pembentukkan sel-sel darah, dan dengan pemberian jus buah kurma selama tujuh hari dapat meningkatkan kadar hemoglobin.

Hemoglobin adalah protein yang membawa oksigen dan merupakan bagian dari eritrosit. Dalam pembentukkan hemoglobin sangat diperlukan zat besi dan protein. Buah kurma kaya akan zat besi yang meningkatkan kadar hemoglobin. Selain itu, kurma juga mengandung protein, serat, glukosa, vitamin, biotin, niasin, dan asam folat. Kurma juga mengandung mineral seperti, kalsium, sodium dan potasium. Kadar protein pada buah kurma sekitar 1,8-2 \%, kadar glukosa sekitar 50-57 \%, dan kadar serat 2-4\%. ${ }^{17}$

Sintesis hemoglobin dimulai didalam proeritroblas dan dilanjutkan sedikit dalam stadium retikulosit. ${ }^{17}$ Saat retikulosit meninggalkan sumsum tulang dan masuk ke dalam aliran darah, retikulosit tetap membentuk sedikit hemoglobin. Kandungan zat besi dapat mensintesis pembentukan heme yang dapat memacu kadar Hemoglobin. Penyerapan zat besi bersifat rate limiting, yang berarti bahwa jika penyerapan zat besi sudah cukup maka tubuh akan mengurangi sendiri penyerapan zat besi tersebut. Besi diangkut oleh darah menuju sumsum tulang untuk membentuk sel-sel darah merah dimana besi merupakan bagian dari hemoglobin protein yang membawa oksigen ke dalam darah. ${ }^{9,}$

Kandungan protein, karbohidrat dan lemak pada kurma mendukung proses sintesis hemoglobin. ${ }^{12}$ Karbohidrat dan lemak membentuk suksinil CoA yang selanjutnya bersama glisin akan membentuk protoporfirin melalui serangkaian proses porfirinogen. Protoporfirin yang terbentuk selanjutnya bersama molekul heme dan protein globin membentuk hemoglobin. ${ }^{17}$ Kandungan buah kurma berupa glukosa, $\mathrm{Ca}, \mathrm{Fe}$, $\mathrm{Zn}, \mathrm{Cu}, \mathrm{P}$ dan niasin mampu memperbaiki kadar hemoglobin pada pasien anemia. ${ }^{2}$

Pada kelompok kontrol dalam penelitian ini terlihat penurunan kadar hemoglobin dengan ratarata penurunannya adalah $0.5 \mathrm{gr} / \mathrm{dl}$. Penu-runan kadar hemoglobin 0.5 - 1 gr/dl dalam waktu seminggu tanpa disertai perdarahan merupakan satu petunjuk ke arah anemia hemolitik. ${ }^{5}$ Hemolisis adalah pemecahan eritrosit dalam pembuluh darah sebelum waktunya. Hal ini disebabkan obat kemoterapi merusak sel-sel yang melakukan pembelahan dalam waktu $6-24$ jam sehingga dapat menurunkan kemampuan sumsum tulang untuk membentuk sel-sel darah. Penurunan jumlah sel-sel darah dapat terjadi dalam waktu yang dapat diprediksi yaitu $7-14$ hari tergantung dari jenis obatnya. ${ }^{6}$

Hasil penelitian didapatkan pada pasien kanker yang menjalani kemoterapi yang mendapat jus buah kurma selama tujuh hari mengalami kenaikan eritrosit dengan rata-rata peningkatannya adalah 0.3 juta/ul. Sedangkan pada pasien kanker yang menjalani kemoterapi tetapi tidak mendapatkan jus buah kurma menunjukkan penurunan eritrosit dengan rata-rata penurunannya adalah 0.23 juta/ul. Tampak adanya hubungan yang bermakna antara jus buah kurma dengan eritrosit pada pasien kanker yang menjalani kemoterapi.

Peningkatan tersebut bermakna secara statistik dan tidak secara klinis. Nilai eritrosit bermakna secara klinis apabila terdapat peningkatan minimal 0.5 juta/ul. ${ }^{17}$ Hasil ini menunjukkan peningkatan eritrosit karena terpenuhinya sumber-sumber pembentukkan eritrosit seperti asam folat, protein yang dikonsumsi responden 
melalui jus buah kurma, sehingga walaupun obat kemoterapi mendestruksi sumsum tulang, dimana terjadi penurunan pembentukkan sel-sel darah, namun dengan pemberian jus buah kurma selama tujuh hari nilai eritrosit meningkat.

Produksi eritrosit dikontrol oleh mekanisme umpan balik negatif yang sensitif ter-hadap suplai oksigen pada jaringan tubuh. Peningkatan produksi eritrosit dapat disebabkan oleh beberapa faktor, yaitu pendarahan, gagal jantung, dan penyakit paru. ${ }^{15}$ Pembentukkan eritrosit membutuhkan bahan-bahan yang dapat diperoleh melalui makanan, antara lain adalah zat besi, vitamin B12, asam folat dan protein. Protein merupakan komponen struktur yang penting pada eritrosit. Tanpa protein dan asam amino, produksi eritrosit menurun dan masa hidupnya berkurang. Salah satu protein yang penting adalah intrinsic factor (IF), yaitu suatu glikoprotein yang diperlukan sistem gastro-intestinal untuk absorbsi vitamin. Proses eritro-poiesis tidak dapat diteruskan tanpa adanya vitamin, asam folat. ${ }^{9,11}$

Hasil penelitian didapatkan pada pasien kanker yang menjalani kemoterapi yang mendapat jus buah kurma selama tujuh hari mengalami kenaikan leukosit dengan rata-rata peningkatannya adalah $0.21 \mathrm{ribu} / \mathrm{ul}$. Sedangkan pada pasien kanker yang menjalani kemoterapi tetapi tidak mendapatkan jus buah kurma menunjukkan penurunan leukosit dengan rata-rata penurunannya adalah 0.18 ribu/ul. Tampak adanya hubungan yang bermakna antara jus buah kurma dengan leukosit pada pasien kanker yang menjalani kemoterapi.

Peningkatan leukosit pada kelompok intervensi dalam penelitian ini tidak bermakna secara klinis. Nilai leukosit bermakna secara klinis apabila terdapat peningkatan minimal 1.5 ribu/ul. ${ }^{17}$ Selama ini obat yang sering digunakan medis untuk meningkatkan leukosit seperti granosyte, neupogen. Harga obat tersebut jauh diatas jus buah kurma dan hanya mampu menaikkan $0.5 \mathrm{ribu} / \mathrm{ul}$ dan terdapat efek samping dari penggunaan obat tersebut. Salah satu efek samping penggunaan neupogen yang paling dirasakan pasien adalah nyeri pada persendian. Selain itu penggunaan neupogen juga tidak menghambat terjadinya trombosit-openia dan anemia. Bahkan risiko terjadinya leukositosis, sehingga pada pasien yang menggunakan neupogen perlu dilakukan pemeriksaan laboratorium secara ketat dan teratur. ${ }^{3}$

Bila peningkatan ini dibandingkan dengan pemberian jus buah kurma maka jus buah kurma maka memiliki efektiftifitas yang hampir sama dalam meningkatkan sel-sel darah, setidaknya konsumsi jus buah kurma lebih murah dan tanpa efek samping. Mengingat bahwa pasien kemoterapi lebih dianjurkan untuk mengkonsumsi makanan alami.

Hasil penelitian didapatkan pada pasien kanker yang menjalani kemoterapi yang mendapat jus buah kurma mengalami kenaikan trombosit dengan rata-rata peningkatannya adalah $29.73 \mathrm{ribu} / \mathrm{ul}$. Sedangkan pada pasien kanker yang menjalani kemoterapi tetapi tidak mendapatkan jus buah kurma menunjukkan penurunan trombosit dengan rata-rata penurunannya adalah $2.87 \mathrm{ribu} / \mathrm{ul}$. Tampak adanya hubungan yang bermakna antara jus buah kurma dengan trombosit pada pasien kanker yang menjalani kemoterapi.

Peningkatan tersebut bermakna secara statistik tetapi tidak secara klinis. Nilai trombosit bermakna secara klinis apabila terdapat peningkatan minimal $75 \mathrm{ribu} / \mathrm{ul} .{ }^{17}$ Dengan demikian konsumsi jus buah kurma dapat meningkatkan pembentukkan sel darah. Selama ini, kenyataan yang ditemukan di klinik bahwa selain pemberian obat untuk meningkatkan sel-sel darah, biasanya juga diberikan transfusi darah, baik untuk meningkatkan trombosit maupun hemoglobin. Transfusi darah sering diberikan pada pasien yang mengalami trombositopenia dan anemia sebelum dilakukan kemoterapi. Peningkatan trombosit yang bermakna setelah pemberian transfusi darah (trombosit) per satu unit darah $(250 \mathrm{ml})$ adalah $20 \mathrm{ribu} / \mathrm{ul} .{ }^{17}$ Namun mengingat berbagai komplikasi dapat terjadi akibat transfusi, maka pemberian jus buah kurma dapat lebih menguntungkan. Komplikasi transfusi darah yang sering terjadi adalah reaksi hemolitik, febris, sensitivitas paru dan bronkhospasme, alergik anafilaktoid, edema paru, keracunan sitras, dan terkadang terjadi penularan infeksi hepatitis B dan hepatitis C.

\section{SIMPULAN}

Gambaran responden pasien kanker yang menjalani kemoterapi berdasarkan umur adalah berada pada rentang usia 41-60 tahun. Siklus 
PROFESI (Profesional Islam) Media Publikasi Penelitian; 2018; Volume 15; No 2.

Website: ejournal.stikespku.ac.id

kemoterapi responden pada rentang 1-5 siklus dengan derajad keganasan berada pada kategori derajad keganasan sedang dan tidak ditemukan derajad keganasan tinggi. Status nutrisi responden dalam peneltian ini adalah baik 53.3\% (9 responden) dan kurang $46.7 \%$ pada kelompok intervensi maupun kontrol.

Terdapat pengaruh jus buah kurma terhadap kadar hemoglobin dengan nilai $\mathrm{p}=0.000$ dan sel darah yaitu eritrosit $(\mathrm{p}=0.000)$, leukosit $(\mathrm{p}=$ $0.006)$ dan trombosit $(0.018)$ pada pasien kanker dengan kemoterapi di RSUD dr.Moewardi.

\section{SARAN}

Bagi tenaga kesehatan mampu menyusun suatu perencanaan tindakan keperawatan tentang pemberian jus buah kurma baik yang bersifat tindakan keperawatan mandiri maupun kolaboratif dengan tim kesehatan lainnya, diantaranya memberikan pendidikan kesehatan tentang jus buah kurma, terutama bagi pasien kanker yang menjalani kemoterapi sebagai bagian dari penerapan ilmu komplementer terhadap bahan-bahan alami serta hasil penelitian ini dapat memberikan masukan bagi rumah sakit untuk membuat protap penatalaksanaan pasien kanker yang menjalani kemoterapi dengan memasukkan pemberian jus buah kurma

Hasil penelitian ini dan dapat menjadi salah satu sumber referensi untuk penelitian selanjutnya dengan melakukan memodifikasi dan mengembangkannya untuk penelitian selanjutnya yaitu mengontrol faktor-faktor yang berpengaruh terhadap kadar hemoglobin dan sel darah pasien kemoterapi. Perlu juga mengembangkan terapi komplementer sebagai salah satu intervensi keperawatan bagi pasien kanker dengan kemoterapi dapat juga dilakukan penelitian lebih lanjut tentang pengaruh buah kurma terhadap sel kanker pasien.

\section{REFERENSI}

Adiatama. (2012). Hubungan antara carcinoma paru dengan efusi pleura, http://ejournals1.undip.ac.id/index.php/m edico/article/download/1325/134

Bath, D. and Mazumdar, B.C. (2008) Comparative Nutritive Values of Palm Saps Before and after Their Partial
Fermentation and Effective Use of Wild Date (Phoenix sylvestris Roxb.) Sap in Treatment of Anemia. Research Journal of Medicine and Medical Sciences, 3(2): 173-176

Brown, Byers, Thompson, Eldridge, Doyle, \& Williams. (2007). Nutrition during and after cancer treatment. A cancer journal for clinicians, 51(3).

Calvagna. (2007). Chemotherapy for cancer treatment.

http://www.healthlibrary.epnet.com/GetContent.aspx?token $=7 \mathrm{e} 9094 \mathrm{f} 4$ c284-4b3a-8f7c$\underline{867 \mathrm{fd} 12 \mathrm{~b} 36 \mathrm{ee} \& \mathrm{chunkiid}=32632}$

Gibney, M.J., Margetts, B.M., Kearney, J.M., Arab, L., (2009), Gizi Kesehatan Masyarakat, p 283, EGC, Jakarta.

Lynne, E., (2013). Chemotherapy for lung cancer treatment. http://www.lung cancer.about.com/od/treatmentoflungcanc er/a/chemolungrx.htm

Nursing, BC. (2006). Complementary and alternative health care: the role of the nurse. http://www.ncbi.nlm.nih.gov/ pubmed/12943134,

Potter, P.A., \& Perry, A.G. (2010). Fundamental Keperawatan $\left(7^{\text {th }}\right.$ ed). Terjemahan Adrina Ferderika Nggie, dan Marina Albar, Jakarta : Salemba Medika

Pravitasari, (2012), Efek ekstrak buah kurma (phoenix dactylifera) terhadap peningkatan kadar hemoglobin (hb). http://www.medicine.uii.ac.id/index2.php ?option $=$ com_content\&do $\_$df $=1 \& \mathrm{id}=70$

Price \& Wilson. (2006). Patofisiologi konsep klinis proses-proses penyakit. Volume 1 . Edisi 6. Jakarta: EGC.

Rakhmawan, Z., (2013). Manfaat buah kurma menurut sudut pandang medis modern, http://www.alhiraindonesia.com

Sotolu, A.O, Kigbu, A.A., Oshinowo, J.A. (2011). Nutritional Evaluation Of Date Palm (Phoenix dactylifera) Seeds and Fruit As Source Of Feeds In Aquaculture. EJEAF Che, 10(5). 
PROFESI (Profesional Islam)

Media Publikasi Penelitian; 2018; Volume 15; No 2.

Website: ejournal.stikespku.ac.id

Stewart BW, Wild CP. (2014). World cancer report 2014. Lyon: International Agency for Research on Cancer.

Syahruddin, E., Marlina, N., dan Hudoyo A., (2012). Efikasi dan toksisitas rejimen sisplatin + etoposid untuk kemoterapi kanker paru jenis karsinoma bukan sel kecil (kpkbsk) stage lanjut. http://www.jurnalrespirologi.org/wpcontent/uploads/2012/01/jri-2012-32-125.pdf.

Velmurugan, C., Vivek, B., Shekar, D.S, Sudha S.P, Sundaram,T., (2010), Shilajit in Management of Iron Deficiency Anemia, Vol. 1, Journal of Pharma ceutical and Biomedical Siences, India
Whitney \& Rolfes. (2008). Understanding nutrition. 11th edition. Belmont: Thomsom Learning, Inc.

Zen, A.T.H., Pertiwi, D., Chodidjah. (2013). Pengaruh Pemberian Sari Kurma (Phoenix dactylifera) terhadap Kadar Hemoglobin- Studi Eksperimental pada Tikus Putih Jantan Galur Wistar yang Diberi Diet Rendah Zat Besi (Fe). Sains Medika, Vol. 5, No. 1, Januari - Juni 2013 